九州大学学術情報リポジトリ

Kyushu University Institutional Repository

\title{
Effect of SiC Reinforced Particle Parameters in the Development of Aluminium Based Metal Matrix Composite
}

Maurya, Manish

Department of Mechanical Engineering, Accurate Institute of Management and Technology

Maurya, Nagendra Kumar

Department of Mechanical Engineering, G L Bajaj Institute of Technology and Management

Bajpai, Vivek

Department of Mechanical Engineering, Indian Institute of Technology

https://doi.org/10.5109/2349295

出版情報：Evergreen. 6 (3)，pp.200-206，2019-09. 九州大学グリーンテクノロジー研究教育センター バージョン：

権利関係 : 


\title{
Effect of SiC Reinforced Particle Parameters in the Development of Aluminium Based Metal Matrix Composite
}

\author{
Manish Maurya $^{1 *}$, Nagendra Kumar Maurya ${ }^{2}$, Vivek Bajpai ${ }^{3}$ \\ ${ }^{1}$ Department of Mechanical Engineering, Accurate Institute of Management and Technology, Greater Noida - \\ 201308, India \\ ${ }^{2}$ Department of Mechanical Engineering, G L Bajaj Institute of Technology and Management, Greater Noida \\ - 201308, India \\ ${ }^{3}$ Department of Mechanical Engineering, Indian Institute of Technology, Dhanbad -826004, India
}

*Author to whom correspondence should be addressed,

E-mail: manishmaurya33@gmail.com

(Received June 5, 2019; accepted September 9, 2019).

\begin{abstract}
This study investigates the effect of addition of SiC particles on Al 6061 alloy. The composites are prepared with varied $(0,2,4,6$ and 8) weight percent of $\mathrm{SiC}$ particles through electromagnetic stir casting technique. Scanning Electronic Microscope (SEM) is employed to examine the microstructure of the fabricated composite and results depict that $\mathrm{SiC}$ content were uniformly dispersed in the Al 6061 matrix. Density of the composite is increased due to high density of $\mathrm{SiC}$ particles in comparison to $\mathrm{Al} 6061$ alloy. Hardness and tensile tests are performed to investigate the mechanical properties of composite. The hardness and tensile strength is significantly improved up to $8 \mathrm{wt} \%$ of $\mathrm{SiC}$ particles. The novelty of this archival work lie in fact that few experiments have been carried out for $\mathrm{Al} 6061 / \mathrm{SiC}$ composite and some significant insight for the electromagnetic stir casting is achieved in the performed experiment.
\end{abstract}

Keywords: Micro-structural analysis, Density, Hardness and Tensile strength.

\section{Introduction}

A composite material is a combination of two or more constituent materials with considerably different physical or chemical characteristics that, when combined, produces a material with properties different from the individual components ${ }^{1)}$. Particulate reinforcement metal matrix composites (MMCs) have tremendous demand in present era due to enhanced mechanical and physical properties, enable them to replace conventional material. Several usage of composite material are found in aerospace, automobile, sports, marine and defence industries ${ }^{2}$. Composite possess isotropic mechanical characteristics in three orthogonal direction combined with quiet low cost accessibility of reinforcement and docility to fabricate. Superior mechanical characteristics and comparatively low cost make them as an appropriate opinion. Dissimilar metals and its alloys such as aluminium and magnesium has been considered and deliberated as metal matrix ${ }^{1-4}$. Among different matrix material present, the tradition of aluminium based MMCs had been increased. Different reinforcements used in aluminium matrix are $\mathrm{SiC}, \mathrm{B}_{4} \mathrm{C}, \mathrm{TiB}_{2}, \mathrm{MgO}, \mathrm{AlN}$, $\mathrm{ZrO}_{2}$, E-glass graphite and $\mathrm{Si}_{3} \mathrm{~N}_{4}{ }^{5-7}$.

Fabrication methodology of aluminium MMC can be categorized into (a) solid state processing such as powder metallurgy and friction stir processing (b) liquid state processing such as stir casting, squeeze casting and spray casting (c) liquid solid process such as compo casting or semi-solid forming ${ }^{8-10)}$. Powder metallurgy is a dominant process to manufacture small composite parts in large scale but is not suitable to produce large components. Liquid state processing has got benefits such as easiness, comparatively less expensive and producing of complicated components. Several liquid state processing techniques available, stir casting process is an attractive method to manufacture the aluminum MMCs ${ }^{11-14)}$.

The main problem occurred in fabricating MMCs by traditional stir casting are porosity, uniform dispersal of reinforced particles, unwanted chemical reactions and poor wettability of reinforced particles ${ }^{15)}$. Homogeneous dispersal of reinforced content in the melt has high impact on the mechanical properties of MMCs. Non uniform dispersal of reinforced particles causes the 
defects in the form of accumulated reinforced particles. These defects are responsible to reduce tensile strength, ductility, fatigue strength, hardness, and toughness of the composite $^{16)}$.

Many researchers have incorporated $\mathrm{SiC}$ particles as reinforcement in $\mathrm{Al}$ metal matrix ${ }^{17-20)}$. Silicon carbide reinforced aluminum MMCs have gained consideration since the cost of $\mathrm{SiC}$ powder is low, having good wettability between Al 6061/SiC composite. SiC particles having low density of $3.21 \mathrm{~g} / \mathrm{cm}^{3}$ had high hardness, strength, elastic modulus, thermal conductivity and superior chemical inertness with low thermal expansion $^{21)}$.

The novelty of present investigation is to prepare $\mathrm{Al}$ 6061/SiC composite (by varying SiC particle from 2 to 8 wt $\%$ by weight) using electromagnetic stir casting technique. Uniform dispersal of reinforced particle in the matrix has been qualitatively examined by SEM to examine the microstructure of reinforced particles. Hardness test and tensile test of the fabricated composite have been used to evaluate the statistical characteristic of hardness distribution for the Al-SiC composites.

\section{Design of Experiment}

Electromagnetic stir casting set up was prepared to fabricate Al 6061 alloy matrix composite constituting 2, 4,6 and 8 wt $\%$ of $\mathrm{SiC}$ particles ${ }^{22)}$. The line diagram of electromagnetic stir casting setup and melting of Al 6061 alloy in muffle furnace is shown in Fig. 1 (a) and (b).

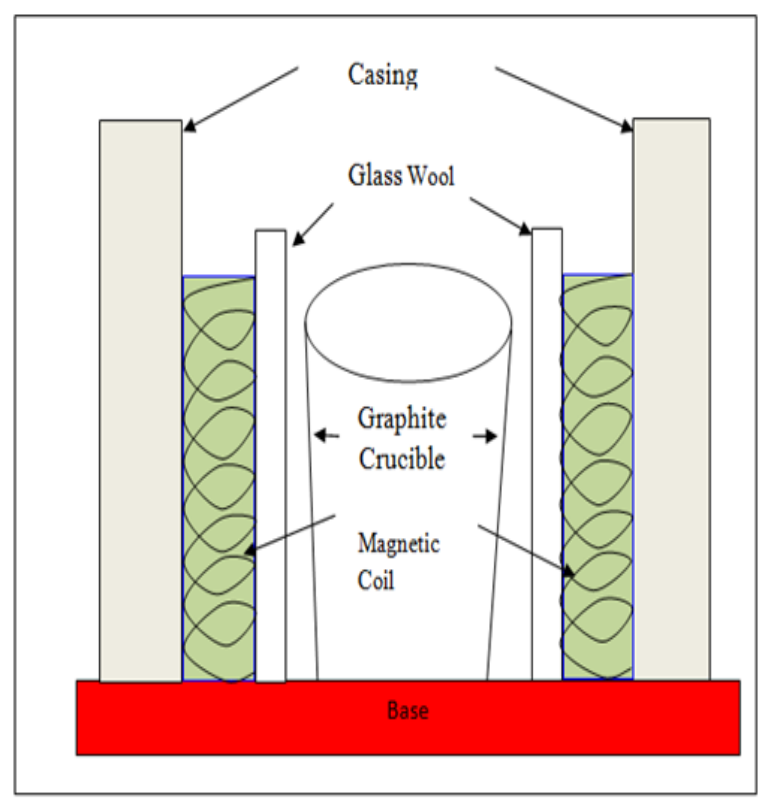

(a)

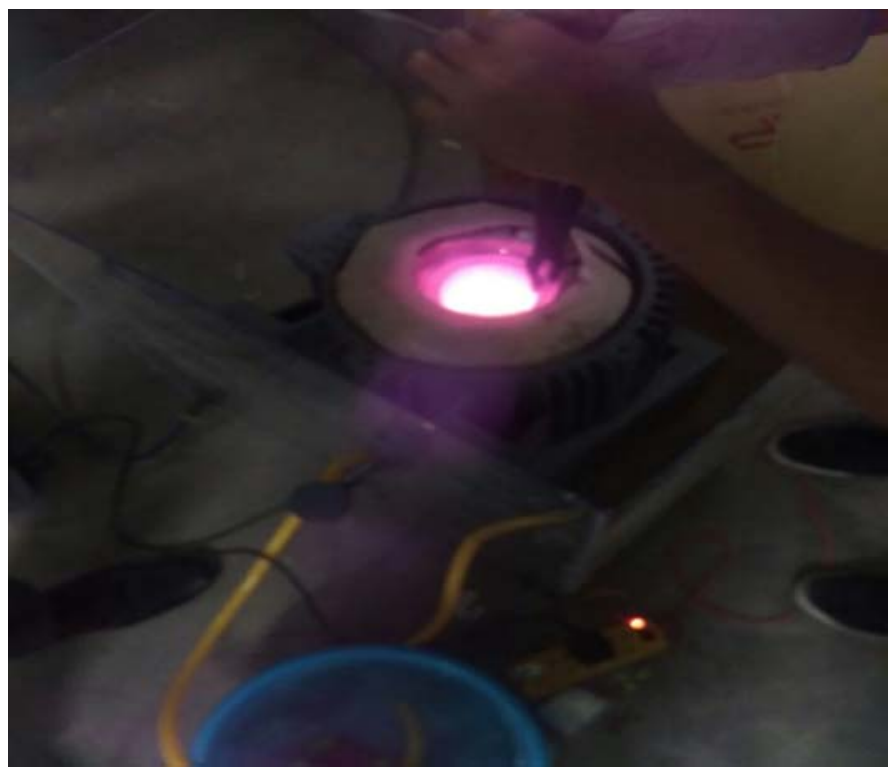

(b)

Fig. 1: (a) Line diagram of stir casting setup (b) Melting of Al 6061 alloy in muffle furnace.

Chemical composition of commercially available Al 6061 alloy is given in Table 1 . The mechanical properties of Al 6061 alloy and SiC contents are shown in Table 2 and Table 3. Cut ingots of Al 6061 alloy having $600 \mathrm{gm}$ weight were kept in a graphite crucible. The crucible was kept above the muffle furnace having temperature range of $400^{\circ} \mathrm{C}$ to $1200^{\circ} \mathrm{C}$ with temperature increment of $10^{\circ} \mathrm{C}$. The muffle furnace was used to melt the material. It was equipped with heating coil of power $3 \mathrm{KW}$ working at $230 \mathrm{~V}$ and $5 \mathrm{~A}$. The $\mathrm{Al} 6061$ alloy was melted at $660^{\circ} \mathrm{C}$ with 1 wt $\%$ magnesium to improve the wettability ${ }^{23)}$. The silicon particles were preheated at $200^{\circ} \mathrm{C}$ to remove moisture content and absorbed gas. SiC particles of 2, 4, 6 and $8 \mathrm{wt} \%$ having average size $30 \mu \mathrm{m}$, kept in aluminum foil were incorporated ( 6 to $8 \mathrm{gm} / \mathrm{min}$ ) in the melt into two steps to avoid clusters of reinforced particles. Electromagnetic stirring was performed for 10 minutes at $450 \mathrm{rpm}$. The melt slurry was poured in the preheated permanents steel mold at $300^{\circ} \mathrm{C}$ for 2 hours having $34 \mathrm{~mm}$ diameter and $78 \mathrm{~mm}$ length. The melt was permitted to cool in atmospheric air.

Table 1: Chemical Composition of $\mathrm{Al} 6061$.

\begin{tabular}{|c|c|c|c|c|c|c|c|c|c|}
\hline $\begin{array}{l}\text { Elem- } \\
\text { ents }\end{array}$ & $\mathrm{Mn}$ & $\mathrm{Cr}$ & $\mathrm{Ti}$ & $\mathrm{Si}$ & $\mathrm{Mg}$ & $\mathrm{Fe}$ & $\mathrm{Cu}$ & $\mathrm{Zn}$ & $\mathrm{Al}$ \\
\hline $\begin{array}{l}\text { Cont- } \\
\text { ents }\end{array}$ & $\begin{array}{l}0 . \\
24\end{array}$ & $\begin{array}{l}0 . \\
8\end{array}$ & $\begin{array}{l}0 . \\
15\end{array}$ & $\begin{array}{l}0 . \\
43\end{array}$ & $\begin{array}{l}0 . \\
14\end{array}$ & $\begin{array}{l}0 . \\
7\end{array}$ & $\begin{array}{l}0 . \\
24\end{array}$ & $\begin{array}{l}0 . \\
25\end{array}$ & $\begin{array}{l}\text { Bala- } \\
\text { nce }\end{array}$ \\
\hline
\end{tabular}


Table 2: Mechanical characteristics of alloy Al 6061.

\begin{tabular}{|l|l|}
\hline Properties & Metric \\
\hline Ultimate Tensile Strength $(\mathrm{MPa})$ & 310 \\
\hline Tensile Yield Strength $(\mathrm{MPa})$ & 276 \\
\hline Hardness $(\mathrm{HRB})$ & 40 \\
\hline Melting Temperature $\left({ }^{\circ} \mathrm{C}\right)$ & $585-692$ \\
\hline Modulus of Elasticity $(\mathrm{GPa})$ & 68.9 \\
\hline Density $(\mathrm{g} / \mathrm{cc})$ & 2.7 \\
\hline
\end{tabular}

Table 3: Properties of Silicon Carbide.

\begin{tabular}{|l|l|}
\hline Properties & Silicon carbide \\
\hline Melting point temperature $\left({ }^{\circ} \mathrm{C}\right)$ & 2973 \\
\hline Thermal conductivity(W/Mk) & 126 \\
\hline Density $\left(\mathrm{g} / \mathrm{cm}^{3}\right)$ & 3.2 \\
\hline Crystal structure & Hexagonal \\
\hline
\end{tabular}

\section{Results and Discussion}

\subsection{Microstructural Analysis}

Metallographic sample of MMC was fabricated as per ASTM E3-95 standard to conduct SEM test. Configuration of the scattering of reinforcement in the matrix alloy was found by scanning electronic microscope. Uniform dispersal of $\mathrm{SiC}$ content was observed through the micrographs obtained from SEM in Fig. 2. The dark indendrite interstice shows the formation of $\mathrm{Mg}_{2} \mathrm{Si}$. In some portion small clusters of $\mathrm{SiC}$ contents was observed due to local accumulation of reinforced particles. This might be possible due to improper mixing of reinforced particles in the Al 6061 alloy.

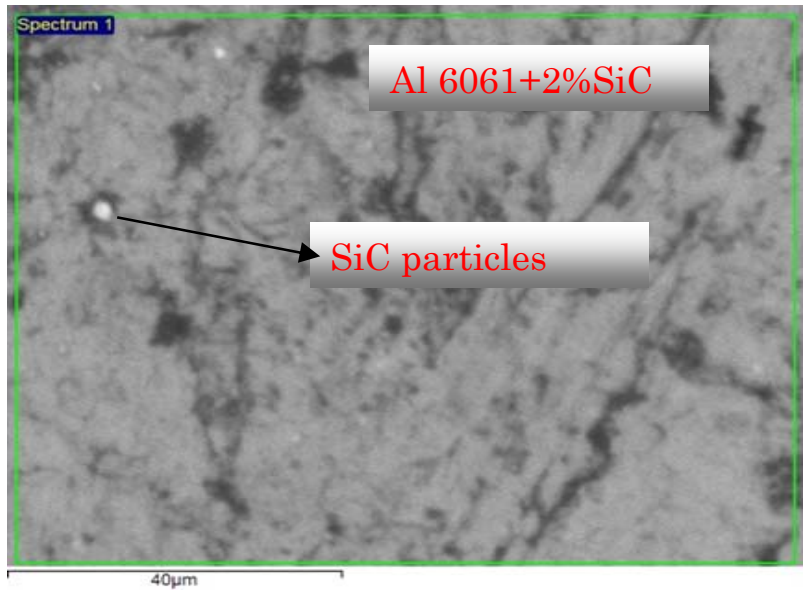

(a)

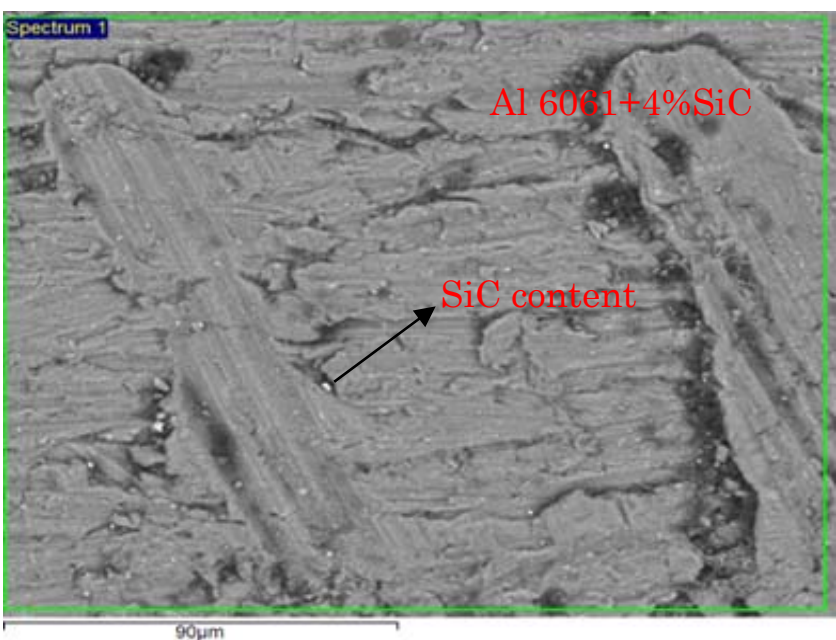

(b)

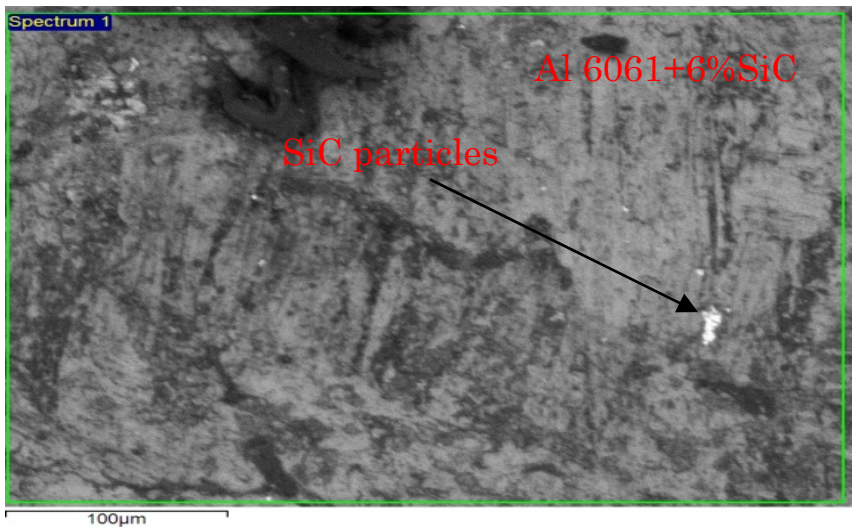

(c)

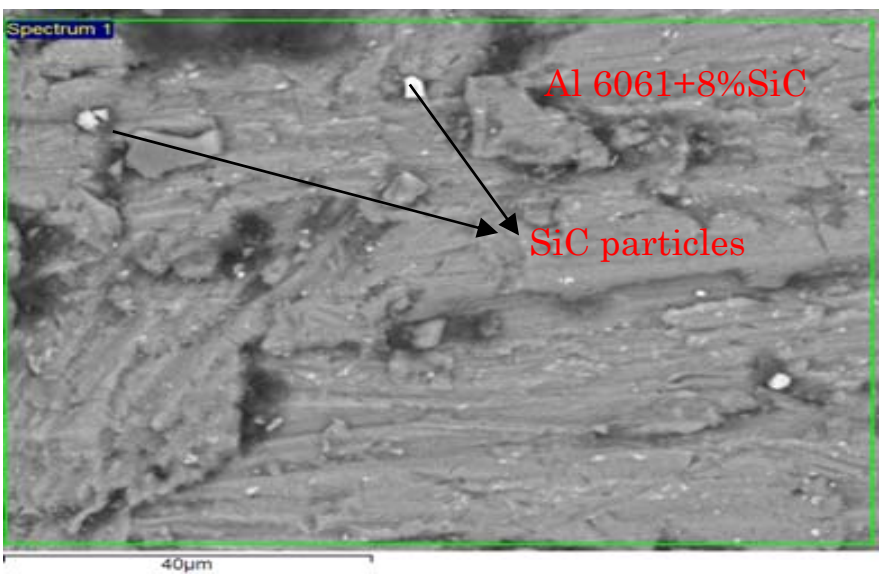

(d)

Fig. 2: SEM images of (a) $\mathrm{Al} 6061+2 \mathrm{wt} \% \mathrm{SiC}$, (b) $\mathrm{Al} 6061+4 \mathrm{wt} \% \mathrm{SiC}$, (c) $\mathrm{Al} 6061+6 \mathrm{wt} \% \mathrm{SiC}$, (d) $\mathrm{Al} 6061+8 \mathrm{wt} \% \mathrm{SiC}$ at $100 \mathrm{X}$.

\subsection{Influence of $\mathrm{SiC}$ particles on density}

The deviation in density with the increase of SiC particles is shown in Table 4. It was observed that with the increase of $\mathrm{SiC}$ content, the density of the composite was increased. The average increase in density was $0.44 \%$ while encapsulating $\mathrm{SiC}$ particles. Theoretical 
density was calculated by the rule of mixture. Composite's density was enhanced to maximum of $1.11 \%$ compared to base alloy $\mathrm{Al} 6061$ with reinforcing $8 \mathrm{wt} \% \mathrm{SiC}$ particles. The cause of increase in density was due to high density of $\mathrm{SiC}$ particles $\left(3.2 \mathrm{~g} / \mathrm{cm}^{3}\right)$ in comparison to density of Al 6061 alloy $\left(2.6 \mathrm{~g} / \mathrm{cm}^{3}\right)$. A similar result of increased density was obtained by Kumar et $\mathrm{al}^{24)}$. Fig. 3 shows the variation of increased density.

Table 4: Theoretical and experimental density of fabricated composite.

\begin{tabular}{|l|l|l|l|l|l|l|}
\hline Material & \multicolumn{1}{|c|}{ Density } & \multicolumn{5}{|c|}{ SiC Wt \% } \\
\hline \multirow{3}{*}{$\begin{array}{l}\mathrm{Al} \\
6061 / \mathrm{SiC}\end{array}$} & $\begin{array}{l}\text { Theoretical } \\
\text { Density }\end{array}$ & 2.7 & 2.71 & 2.72 & 2.73 & 2.74 \\
\cline { 2 - 7 } & $\begin{array}{l}\text { Experimental } \\
\text { Density }\end{array}$ & 2.68 & 2.69 & 2.71 & 2.72 & 2.73 \\
& & & & & & \\
\hline
\end{tabular}

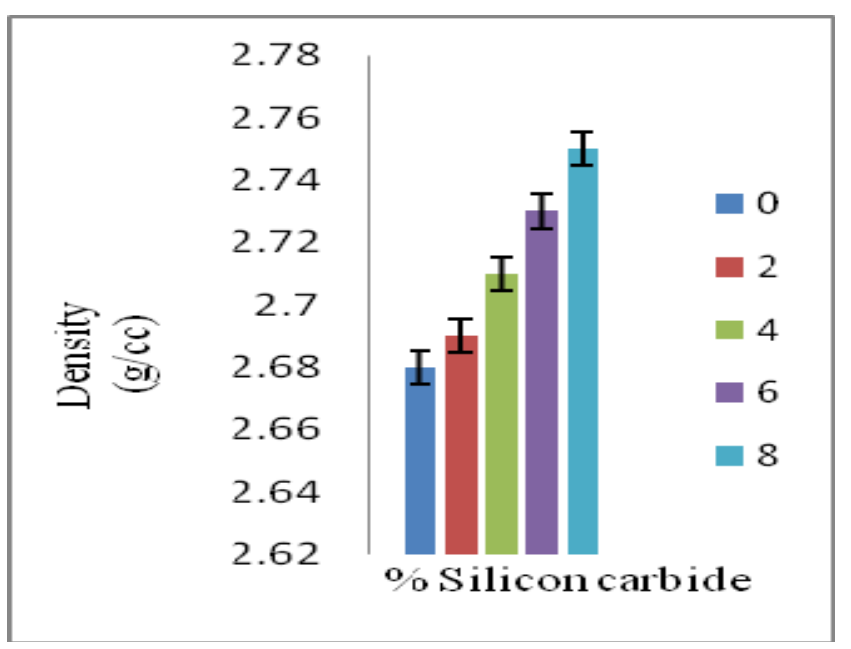

Fig. 3: Variation of density with increased $w t \%$ of $\mathrm{SiC}$ particles.

\subsection{Effect of SiC particles on hardness}

Rockwell hardness test was performed to find the influence of $\mathrm{SiC}$ particles on the matrix hardness. $100 \mathrm{~kg}$ of load was applied and indenter used was 1/16'. Composite having greater hardness has greater resistance to deform.

Samples were prepared as per ASTM E18-12 to measure the hardness ${ }^{25)}$. It was found that with the increase of $\mathrm{SiC}$ content, the hardness of the $\mathrm{Al}$ 6061/SiC composite was increased. Improved hardness was observed due to resistance exhibited to indentation by silicon particles. Hardness of the composite was increased due to the reason that silicon particles bear the major load transferred by Al 6061. Table 5 shows the hardness of composites with varied $\mathrm{SiC} w t \%$. The maximum hardness was achieved 51 HRB with incorporating $8 \mathrm{wt} \% \mathrm{SiC}$ particles. Fig. 4 shows the variation of hardness with the increased $w t \%$ of the reinforcement. The hardness of $\mathrm{Al} 6061 / 8 \mathrm{wt} \% \mathrm{SiC}$ composite was maximum and enhanced to $27.5 \%$ in comparison to base alloy $\mathrm{Al} 6061$.

Table 5: Hardness of the composites with varied $\mathrm{SiC} w \mathrm{t} \%$.

\begin{tabular}{|c|c|c|}
\hline Sample No. & \% of SiC & Hardness (HRB) \\
\hline 1 & 0 & 40 \\
\hline 2 & 2 & 42 \\
\hline 3 & 4 & 43 \\
\hline 4 & 6 & 46 \\
\hline 5 & 8 & 51 \\
\hline
\end{tabular}

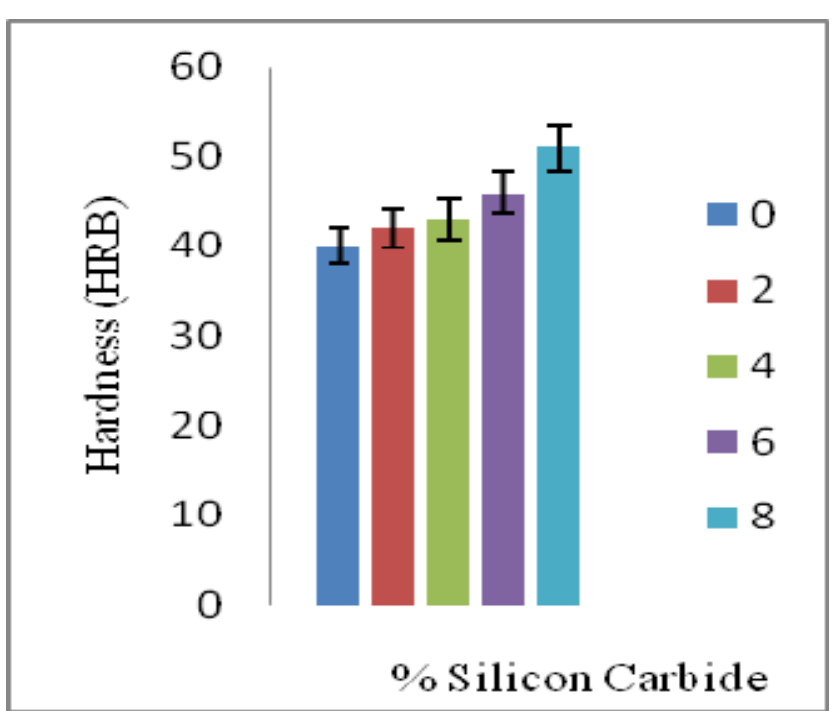

Fig. 4: Variation of hardness in the composites with varied $\mathrm{SiC} \mathrm{wt} \%$.

\subsection{Influence of $\mathrm{SiC}$ particles on tensile strength}

The tensile test samples were prepared as per ASTM E8-04 standard [25]. The w/B ratio was 6.4, which does not satisfy the suggested value in the range of $2<w / B<4$, yet it was an acceptable value due to small thickness of the specimen. Tensile test sample is shown in Fig. 5.

Machining scratches and surface defects were reduced by polishing the surface and rubbing emery paper. Tensile test was conducted on UTM (FIE/UTN-40). The tensile strength was assessed at cross head speed of 1 $\mathrm{mm} / \mathrm{min}$. The ultimate tensile strength was increased with the increase of $\mathrm{SiC} w \mathrm{wt} \%$. Table 6 shows the tensile strength of the $\mathrm{Al} 6061 / \mathrm{SiC}$ composite with varied $\mathrm{SiC}$ content. The maximum ultimate tensile strength was found to be $158 \mathrm{MPa}$ for $\mathrm{Al} 6061 / 8 \mathrm{wt} \% \mathrm{SiC}$ composite. The variation of tensile strength is shown in Fig. 6. The improvement in tensile strength was due to embedded hard $\mathrm{SiC}$ particles in $\mathrm{Al} 6061$ alloy. SiC particles resist the plastic flow of composites when subjected to strain [4]. 


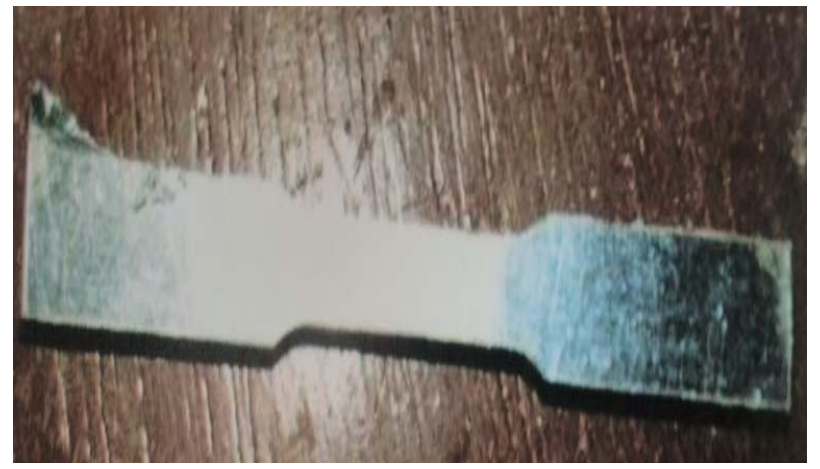

Fig. 5: Specimen for tensile test.

Table 6: Ultimate tensile strength of the $\mathrm{Al} 2021 / \mathrm{SiC}$ composites with varied $\mathrm{SiC}$ wt \%.

\begin{tabular}{|c|c|c|}
\hline Sample No. & SiC wt\% & $\begin{array}{c}\text { Ultimate Tensile Strength } \\
(\mathrm{MPa})\end{array}$ \\
\hline 1 & 0 & 276 \\
\hline 2 & 2 & 281 \\
\hline 3 & 4 & 287 \\
\hline 4 & 6 & 291 \\
\hline 5 & 8 & 298 \\
\hline
\end{tabular}

The UTS was enhanced with the increased $\mathrm{SiC}$ content. Fig. 7 clearly demonstrates the increased UTS. Al $6061 / 8 \mathrm{wt} \% \mathrm{SiC}$ composite had maximum UTS of 324.7 $\mathrm{MPa}$. With the improved UTS, percentage elongation of the $\mathrm{SiC}$ reinforced composite was reduced. High strength of $\mathrm{SiC}$ composite had reduced the ductility of the prepared composite. Beyond $8 \mathrm{wt} \%$ of $\mathrm{SiC}$ content, the ductility was significantly decreased. The reduction of percent elongation is given in Fig. 8. Al 6061/8wt $\% \mathrm{SiC}$ composite had maximum reduced elongation.

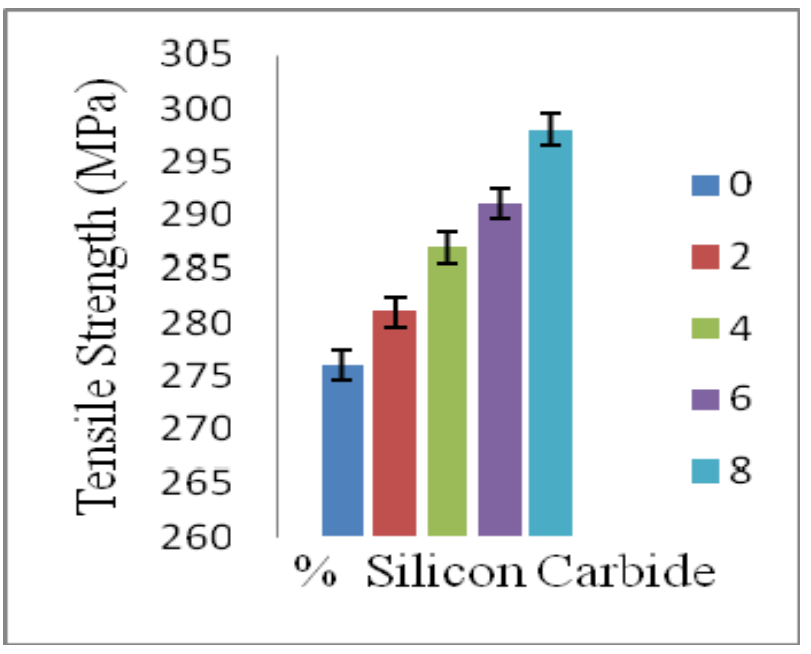

Fig. 6: Tensile strength of $\mathrm{SiC}$ reinforced composite.

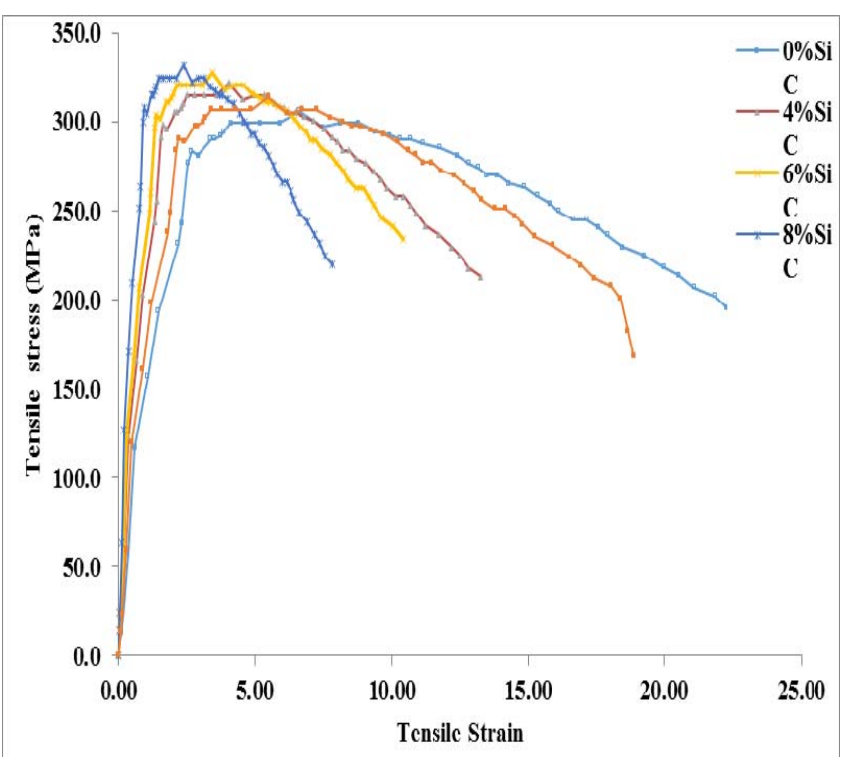

Fig. 7: Stress v/s strain diagram of Al 6061 composite with varying $\mathrm{wt} \%$ of $\mathrm{SiC}$

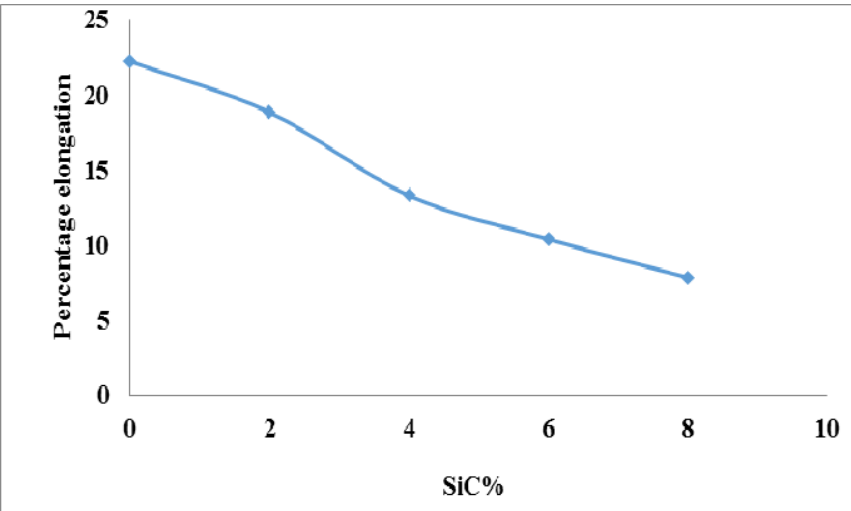

Fig. 8: Percentage elongation of $\mathrm{Al} 6061 \mathrm{v} / \mathrm{s}$ addition of $\mathrm{SiC} \%$.

\section{Conclusion}

In this present work, series of Al 6061 alloy matrix composite containing 2, 4, 6, and $8 \mathrm{wt} \% \mathrm{SiC}$ content were casted using electromagnetic stir casting technique. The following inferences were concluded;

- Homogeneous and uniform dispersion of $\mathrm{SiC}$ particles was observed in the aluminum matrix.

- The density of the composite was increased with the increase of silicon carbide content. $1.11 \%$ density of the composite was increased with incorporating $8 \mathrm{wt} \%$ of silicon carbide.

- Considering the result of Rockwell hardness test, the maximum hardness was 51 HRB. $27.5 \%$ hardness was enhanced to $\mathrm{Al} 6061 / 8 \mathrm{wt} \% \mathrm{SiC}$ in comparison to base alloy $\mathrm{Al} 6061$.

- The maximum tensile strength was enhanced to $298 \mathrm{MPa}$ for $\mathrm{Al} 6061 / 8 \mathrm{wt} \% \mathrm{SiC}$ composite in reference to Al 6061 alloy, having $276 \mathrm{MPa}$. Embedded hard SiC particles had improved the 
tensile strength of fabricated composite.

- The UTS was improved with the addition of $\mathrm{SiC}$ particles. Al $6061 / 8 \mathrm{wt} \% \mathrm{SiC}$ composite had maximum UTS of $324.7 \mathrm{MPa}$ in context to base alloy, having 299.3 $\mathrm{MPa}$. With the enhanced UTS, the ductility of the composite was reduced.

\section{Declaration of conflicting interest}

The author(s) declared no potential conflicts of interest with respect to the research, authorship, and/or publication of this article.

\section{Acknowledgement}

The author(s) received no financial support for the research, authorship, and/or publication of this article.

\section{References}

1) N. Fatchurrohman, I. Iskandar, S. Suraya, K. Johan. Sustainable analysis in the product development of Al-Metal Matrix Composites Automotive Component. Applied Mechanics and Materials, 695,2 (2015).

2) M. Maurya, N.K. Maurya. Fabrication of A359 Alloy Reinforced With B4C Particulates \& Characterization of Mechanical Properties. International Journal of Advanced Research in Science and Engineering, 6 ,532 (2017).

3) S. Kumar, Suman K.N.S, Tara Sasanka C., Ravindra K. , Palash Poddar Venkata Siva S.B. Microstructure, mechanical response and fractography of AZ91E/A12O3 (p) nano composite fabricated by semi solid stir casting method. Journal of Magnesium and Alloys 5,48 (2017).

4) Manish Maurya , Sudhir Kumar, and Vivek Bajpai, Assessment of the mechanical properties of aluminium metal matrix composite: A review, Journal of Reinforced Plastics and Composites, 38,267 (2019).

5) M.M. Khan, Gajendra Dixit. Erosive wear response of SiCp reinforced aluminium based metal matrix composite: Journal of Mechanical Engineering and Sciences, 11, 2401(2017).

6) A. A. Premnath, T. Alwarsamy, T. Rajmohan, R. Prabhu. The influence of alumina on mechanical and tribological characteristics of graphite particle reinforced hybrid Al-MMC, Journal of Mechanical Science and Technology, 28,4737(2014).

7) Harini Sosiati, Yankeisna Auda Shofie and Aris Widyo Nugroho, Tensile Properties of Kenaf/E-glass Reinforced Hybrid Polypropylene (PP) Composites with Different Fiber Loading, EVERGREEN Joint Journal of Novel Carbon Resource Sciences \& Green Asia Strategy, 5, 1(2018).

8) S. Selvi, E. Rajasekar. Theoretical and experimental investigation of wear characteristics of aluminum based metal matrix composites using RSM. Journal of Mechanical Science and Technology, 29, 785 (2015).

9) T. Etter, J. Kuebler, T. Frey, P. Schulz, J.F. Loffler, P.J. Uggowitze, Strength and fracture toughness of interpenetrating graphite/aluminium composites produced by the indirect squeeze casting process, Materials Science and Engineering: A, 386, 61, (2004),

10) Soltani, S, Azari Khosroshahi, R., Taherzadeh Mousavian, Rare Metals. 36, 581 (2017).

11) H R Ezatpour, Parizi M Torabi, S A Sajjadi, Microstructure and mechanical properties of extruded $\mathrm{Al} / \mathrm{Al} 2 \mathrm{O} 3$ composites fabricated by stir-casting process, Transactions of Nonferrous Metals Society of China, 23,126(2013).

12) Soon Jik Hong, Hong Moule Kim, Dae Huh C, Suryanarayanana and Byong Sun Chun, Effect of clustering on the mechanical properties of $\mathrm{SiC}$ particulate-reinforced aluminum alloy 2024 metal matrix composites, 347, 198 (2003).

13) H.G. Prashantha Kumar ,M. Anthony Xavior, Assessment of Mechanical and Tribological Properties of Al 2024- SiC - Graphene Hybrid Composites, Procedia Engineering, 174, 992 (2017).

14) Stefano Spigarelli, Marcello Cabibbo. Enrico Evangelista, Terence G Langdon, Creep properties of an Al-2024 composite reinforced with $\mathrm{SiC}$ particulates, Materials Science and Engineering: A, 328, 39 (2002).

15) P. Subramanya Reddy, R. Kesavan, B Vijya Ramnath, Evaluation of Mechanical Properties of Aluminum Alloy (A12024) Reinforced with Silicon Carbide (SiC) Metal Matrix Composites, Solid State Phenomena, 263, 184, (2017).

16) S. V. Nair, J. K. Tien \& R. C. Bates SiC-reinforced aluminium metal matrix composites, International Metals Reviews, 30, 275(1985).

17) I. Narasimha Murthy, D. Venkata Rao, J.Babu Rao, Microstructure and mechanical properties of aluminum-fly ash nano composites made by ultrasonic method, Materials \& Design, 35, 55 (2012).

18) S.T. Mavhungu, E. T. A. Kinlabi, M. A. Onitiri, F.M. Varachia. AMC for industrial use: Advances and Trends. Procedia Manufacturing, 7,178, (2016).

19) Rajesh Kumar Bhushan, Sudhir Kumar, Optimization of porosity of $7075 \mathrm{Al}$ alloy $10 \% \mathrm{SiC}$ composite produced by stir casting process through Taguchi method. Int. J. Materials Engineering Innovation, 1, 116 (2009).

20) J. Hashim, L. Looney, M.S.J. Hashmi. Metal matrix composites: production by the stir casting method. Journal of Materials Processing Technology, 92, 1(1999).

21) R.S. Rana, Rajesh Purohit, V. K. Soni, S. Das. Characterization of Mechanical Properties and Microstructure of Aluminium Alloy-SiC Composites. 
Materials Today: Proceedings, 2,1149 (2015).

22) G.B. Veeresh Kumar, C.S.P. Rao, N. Selvaraj, M. S. Bhagyashekar, Studies on Al6061-SiC and A17075-A12O3 Metal Matrix Composites, Journal of Minerals \& Materials Characterization \& Engineering, 9,43 (2010).

23) D.A. Saheb, Aluminum silicon carbide and aluminum graphite particulate composites. ARPN J. Eng. Appl. Sci. 6, 41(2011).

24) A. Saravanakumar, P. Sasikumar, S. Sivasankaran. Synthesis and mechanical behavior of AA 6063-x wt. \% Al2O3-1\% Gr (x = 3, 6, 9 and 12 wt. \%) hybrid composites. Procedia Engineering, 97, 951 (2014).

25) S.M. Kumar, R. Pramod, H.K. Govindaraju. Evaluation of mechanical and wear properties of Aluminium AA430 reinforced with $\mathrm{SiC}$ and $\mathrm{MgO}$. Materials Today: Proceedings, 4, 509 (2017). 